\title{
Teknologi Penghasilan Tembikar Tradisional Terenang di Temin Kraf
}

\author{
The Production Technology of Traditional Pottery Terenang in Temin Kraf \\ Mohd Zamani Mohd Nor Peah', Nubli Muhammad² \& Hamdzun Harun ${ }^{3}$ \\ ${ }^{1}$ IPG Kampus Tengku Ampuan Afzan, Kuala Lipis, Pahang \\ ${ }^{2}$ Pusat Bahasa Moden dan Sains Kemanusiaan, Universiti Malaysia Pahang, Pekan, Pahang \\ ${ }^{3}$ Pusat Citra Universiti, Universiti Kebangsaan Malaysia, Bangi, Selangor \\ email: zact73@gmail.com
}

\begin{abstract}
Abstrak
Terenang merupakan antara produk tembikar tradisional tempatan di Semenanjung Malaysia selain daripada Labu Sayong dan tembikar Mambong. Kegiatan penghasilan Terenang berpusat di Kampung Pasir Durian dan Temin Kraf di daerah Jerantut, Pahang. Seiring dengan kemajuan hari ini, pembuatan tembikar tradisional juga mengalami perubahan dari sudut penggunaan teknologi seperti yang berlaku pada penghasilan Labu Sayong di Perak. Penggunaan teknologi moden dalam proses pembuatan sangat membantu dalam melestarikan kegiatan ini daripada pupus dalam arus kemajuan. Namun persoalannya adakah kegiatan penghasilan tembikar Terenang turut sama mengunakan teknologi moden di dalam proses pengeluaran. Penyelidikan ini menggunakan pendekatan kajian kualitatif yang merakam secara deskriptif melalui kaedah pemerhatian, temubual dan analisis dokumen ke atas proses penghasilan Terenang di Temin Kraf. Data-data yang diperolehi telah dianalisis dengan mengkategorikan ia berdasarkan tema-tema yang telah dikenal pasti. Dapatan kajian menunjukkan terdapat penggunaan teknologi moden pada kegiatan pembuatan tembikar tradisional Terenang. Ini dapat diperhatikan pada proses bahan utama, proses pembuatan, proses dekorasi, dan kaedah pembakaran. Usaha Temin Kraf yang memanfaatkan penggunaan teknologi moden merupakan satu langkah yang membawa kegiatan ini ke satu tahap baharu yang dapat mempelbagaikan jenis dan reka bentuk Terenang serta menambahkan jumlah pengeluaran yang dapat dilakukan dengan segera. Bagaimanapun kajian ini menyarankan perlunya suatu usaha yang proaktif dan drastik diambil oleh pihak kerajaan untuk memastikan bahawa warisan ini akan terus dilestarikan untuk dihayati oleh generasi akan datang.
\end{abstract}

Kata kunci warisan, tembikar, Terenang, teknologi, kraf

\begin{abstract}
Terenang is one of the local traditional earthenware products in Peninsular Malaysia other than Labu Sayong and Mambong pottery. Terenang production activities centered in Kampung Pasir Durian and Temin Kraf in Jerantut, Pahang. Along with the modern advancement, the manufacturing of traditional pottery is also experiencing changes in terms of technology usage as demonstrated through the Labu Sayong's production in Perak. The use of modern technology in the manufacturing process is very helpful in preserving the activity of extinction in development. However, the question is whether the Terenang pottery production activity uses the same modern technology during the distribution process. This research uses qualitative research approach that captures descriptively through observation, interview and document analysis towards the Terenang production process at Temin Kraf. The results showed that the use of modern technology in the manufacture of traditional pottery craft Terenang at Temin Kraf. This can be observed in the process of primary materials, the manufacturing process, the decor, and the combustion method. Temin Kraf's effort in utilizing the use of modern technology is a step that brings this pottery activity to another new level that can diversify the types and designs of Terenang as well as being able to increase the distribution amount immediately. However, this study suggests the need for a proactive and drastic efforts taken by the government to ensure that this legacy will continue to be preserved in order to be appreciated by future generations.
\end{abstract}

Keywords heritage, pottery, Terenang, technology, crafts 


\section{PENGENALAN}

Terenang merupakan salah satu produk tembikar tradisional yang dikeluarkan di daerah Jerantut, Pahang. Kegiatan ini berpusat di Kampung Pasir Durian, Jerantut sejak turun temurun. Kampung ini berada di tebing Sungai Tembeling tidak jauh dari Kuala Tembeling yang terletaknya pertemuan Sungai Jelai dan Sungai Tembeling yang membentuk Sungai Pahang. Kawasan ini terkenal sebagai tapak arkeologi ketamadunan awal manusia di negeri Pahang. Menurut Ensiklopedia Sejarah dan Kebudayaan Melayu (1999), Sungai Tembeling merupakan kawasan penempatan manusia yang dikesan semenjak zaman prasejarah. Penemuan kajian arkeologi mendapati banyak penemuan artifak kebudayaan neolitik dan logam di beberapa tapak prasejarah. Terdapat 12 tapak arkeologi prasejarah di sepanjang Sungai Tembeling yang telah dikenal pasti iaitu Nyong, Batu Pasir Garam, Teluk Lubuk Puai, Bukit Jong, Kampung Pagi, Kampung Bantal, Jeram Koi, Bukit Komel, Kampung Mat Daling, Kampung Gusai dan Kampung Pengau. Semasa banjir besar yang terjadi sekitar tahun 1926 dan 1927, terdapat artifak prasejarah telah ditemui seperti alat batu, tembikar dan alat logam. Penemuan ini menjadikan kawasan sepanjang Sungai Tembeling kawasan yang mempunyai potensi untuk kajian bidang arkeologi dan seni budaya.

\section{LATAR BELAKANG KAJIAN}

Terenang merupakan salah satu produk yang dihasilkan dalam set tembikar tradisional Tembeling di Kampung Pasir Durian. Nama Terenang telah disebut oleh Tun Seri Lanang dalam Sulalatus Salatin (1612) yang menyatakan:

"Barang maklumlah Duli yang Dipertuan, inilah banyak bilangan harta hamba sahaya patik itu yang disuratkan tiga hari tiga malam, pertama-tama harta patik itu talam tiada berbibir lagi pasu satu, dan bokor pecah atas Terenang Pahang. Sumbing satu, dan pinggan retak China satu, dan mangkuk retak satu, dan piring karang satu, dan periuk tembaga satu putus bibirnya, dan belanga Keling tembaga satu; dan budak tiga orang-seorang si Berkat namanya, berkayuh di buritan, lagi membawa pedang; Selamat seorang namanya, duduk menimba ruang, lagi membawa epok, lagi membawa pengudat."

Pernyataan ini menunjukkan bahawa Terenang mengesahkan kewujudannya semenjak dulu lagi. Syed Ahmad Jamal (1997) menyatakan Terenang menyerupai bentuk bersifat logam.

\section{Sejarah Lokasi \& Latar Belakang}

Kegiatan penghasilan tembikar Tembeling bermula di Kampung Pasir Durian yang terletak di tebing kanan Sungai Tembeling. Sungai Tembeling merupakan sungai yang membentuk Sungai Pahang apabila bertemu dengan Sungai Jelai di Kuala Tembeling. Menurut Ensiklopedia Sejarah dan Kebudayaan Melayu (1999), Sungai Tembeling merupakan kawasan penempatan manusia yang dikesan semenjak zaman prasejarah. Penemuan kajian arkeologi mendapati banyak penemuan artifak kebudayaan neolitik dan logam di beberapa tapak prasejarah di sepanjang Sungai Tembeling yang mempunyai potensi untuk kajian bidang arkeologi dan seni budaya.

Kampung Pasir Durian boleh dilawati dengan menaiki bot dari jeti Kuala Tembeling. Perjalanan melalui jalan darat pula memakan masa sekitar 45 minit iaitu kira-kira $37 \mathrm{~km}$ dari bandar Jerantut melalui Felda Padang Piol yang turut menghubungkannya dengan Taman Negara. Asal-usul nama Kampung Pasir Durian dikatakan berasal daripada kesuburan tanah di kawasan tersebut yang menyebabkan banyak pokok durian telah hidup dengan subur. Selain itu, juga dikatakan bahawa setiap orang yang menghilir atau mudik akan berhenti mengambil buah durian yang jatuh di atas pasir sungai, hingga akhirnya terkenal tempat persinggahan itu dengan Kampung Pasir Durian.

Pada tahun 1919, pihak British telah merizabkan tanah seluas 6 ekar dikenali sebagai 'tanah miskin' berbentuk segi lima dan kawasan ini dikenali dengan nama Sungai Periuk kerana bersempadan 
dengan sebatang sungai dan nama "periuk" itu pula berkaitan dengan kegiatan penduduk kampung yang membuat tembikar. Kawasan ini terletak kira-kira 3.25 dari kampung Pasir Durian. Tanah di kawasan rizab ini dipercayai mengandungi sejenis tanah liat yang paling sesuai untuk membuat Terenang, periuk, belanga Tembeling. Sebelum tanah kawasan ini dirizabkan oleh pihak British, tanah di sini telah digunakan semenjak turun temurun. Banjir pada tahun 1926 (banjir merah), 1931 dan 1970 telah banyak mengubah struktur dan keadaan kandungan tanah. Walau bagaimanapun, lawatan pengkaji ke tapak rizab tersebut mendapati laluan untuk mengambil tanah telah tertutup dengan belukar malah saiz tanah semakin mengecil kerana penduduk kampung telah menanam pokok getah atau pokok sawit.

Sekitar awal tahun 80-an, Kementerian Pembangunan Negara dan Luar Bandar telah memilih Kampung Pasir Durian untuk tujuan penubuhan sebuah industri kampung disebabkan oleh kemahiran membuat tanah liat yang terkenal dan mempunyai potensi untuk berkembang. Untuk tujuan itu, satu peruntukan khas telah diberikan. Penubuhan koperasi dan bengkel tanah liat ini telah diusahakan oleh Pejabat Daerah Jerantut, Kemas, Jabatan Pembangunan Koperasi dan Perbadanan Kemajuan Kraftangan Malaysia cawangan negeri Pahang yang terletak di Songsang, Temerloh. Projek ini dikenali dengan nama Projek Koperasi Industri Kampung Pasir Durian. Sebuah bengkel telah dibina di atas tanah bilik mantan ketua kampong iaitu, Tuan Haji Abdul Rahman bin Khatib Dollah untuk memudahkan kerja-kerja berkaitan dijalankan. Sebuah bangunan bengkel telah dibina dan mendapat bantuan mesin daripada Kementerian Negara dan Luar Bandar melalui Kemas iaitu mesin membentuk, mesin pusing kuasa tangan dan mesin pusing kuasa kaki. Selain daripada itu bengkel ini juga dibekalkan dengan dapur, janakuasa elektrik dan almari. Di bawah projek ini para pengiat tembikar sekitar Kampung Pasir Durian telah disatukan di bawah satu pengurusan untuk memudahkan pemasaran barangan serta mendapat keuntungan yang lebih. Pada 5 April 1985, koperasi ini telah dirasmikan oleh Perdana Menteri ketika itu, Datuk Seri Dr. Mahathir Mohammad. Barangan yang dihasilkan ialah Terenang besar, Terenang kecil, belanga, periuk, buyung dan bekas habuk rokok. Antara pasaran barangan ini ialah Rumah Karyaneka Pahang di Kuala Lumpur, Balai Seni Visual Negara dan Karyaneka Negeri di Kuantan, tempahan-tempahan tempatan, pelancong-pelancong dan permintaan individu. Walau bagaimanapun hasil daripada tinjauan dan temubual yang dilakukan, koperasi ini didapati sudah tidak lagi beroperasi kerana tiada kesediaan dalam kalangan pengiat untuk berubah terutamanya daripada segi teknologi pembuatan terkini seperti penggunaan peralatan moden, dekorasi serta tatacara perniagaan yang lebih sistematik. Selain itu, faktor fungsi tembikar Tembeling yang terhad berbanding alatan moden yang diperbuat daripada plastik turut menyumbang kepada kemerosotan penghasilan tembikar. Hal ini juga dapat dikaitkan dengan sikap para pengiat lebih selesa dengan cara tradisional dan tiada usaha untuk membuat penyelidikan pembangunan dalam produk tembikar yang mereka buat.

Perkembangan kegiatan tembikar tradisional di Pahang tidaklah sepantas di Perak. Kajian oleh Azmi Ariffin et al. (2010) menunjukkan 100 pengusaha yang wujud di Sayong berbanding di Jerantut di mana satu-satu perusahaan yang ada dan masih bertahan ialah Temin Kraf. Ia terletak di Kampung Temin daerah yang sama dengan Kampung Pasir Durian tetapi jarak antara kedua tempat ini sekitar $40 \mathrm{~km}$. Temin Kraf telah bermula pada awal tahun 80-an dan sehingga hari ini hanya tinggal dua penggiat yang masih aktif di situ iaitu Encik Muhamad dan Encik Zainal. Kewujudan Temin Kraf merupakan satu pewaris kemahiran kerja tangan tembikar tradisional negeri Pahang. Pengeluaran produk tembikar Tembeling masih diteruskan terutamanya Terenang.

\section{Spesifikasi Terenang}

Kajian lepas menyatakan tembikar tradisional Tembeling terdiri daripada belanga, bekas perasapan, periuk tanah, bekas pembakar kuih, Terenang dan buah delima (Zahirah Harun, 2016). Kajian oleh Salwa Ayob (2011) pula menyatakan labu, belanga, perasapan, kendi, periuk air, periuk nasi dan Terenang. Produk tembikar Tembeling yang paling dikenali ialah Terenang iaitu berfungsi sebagai bekas untuk mengisi air untuk tujuan minum dan perubatan.

Terenang mempunyai bentuk unik yang boleh dibahagikan kepada beberapa bahagian. Salwa Ayob (2011) menyatakan nama-nama bahagian yang terdapat pada Terenang, umumnya boleh dibahagikan kepada tiga bahagian utama seperti berikut: 
i. $\quad$ Penutup - tangkai, bibir

ii. Badan - mulut, leher, dada,

iii. Pelapik - tali air, birai, bontot, kaki

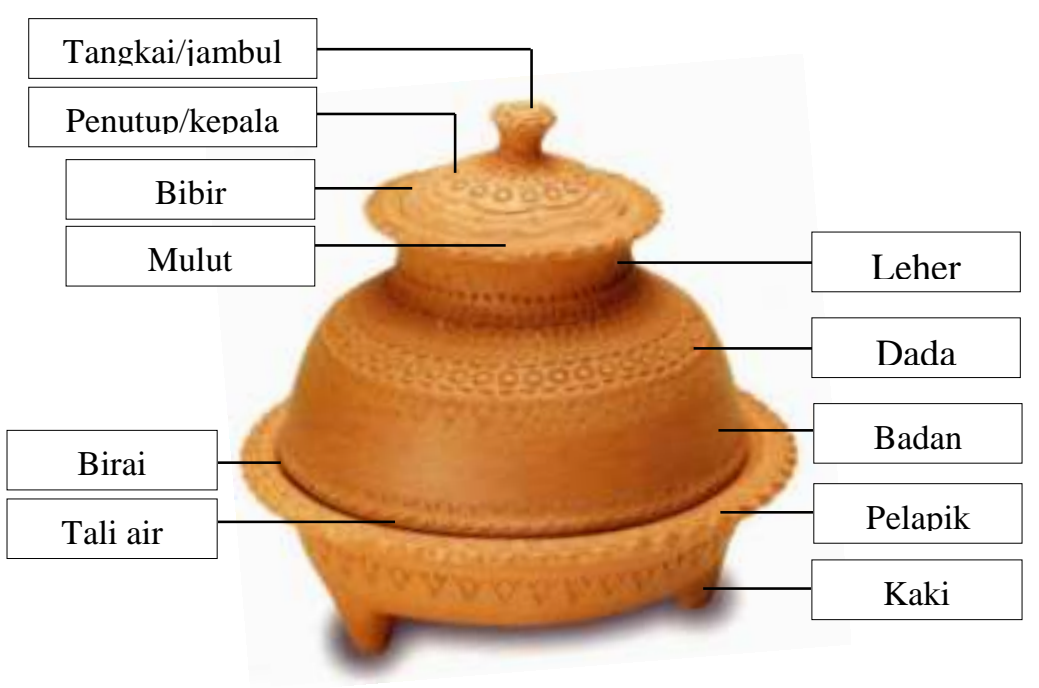

Rajah 1 Bahagian Terenang

\section{Komposisi Tanah Liat}

Menurut Ivor H. N. Evans (1922) menyatakan tanah liat yang digunakan oleh wanita bagi menghasilkan tembikar adalah asalnya berwarna kuning sebelum dibakar. Pandangan ini selari dengan dapatan kajian Zainal Zakaria dan Oskar Hasdinor Hassan (2006) yang mengatakan bahawa penghasilan tembikar tradisional tempatan adalah berasaskan sumber tanah liat iaitu terracotta. Lebih jelas lagi ialah pandangan oleh Salwa Ayob (2011) yang menyatakan bahawa ciri-ciri tanah yang baik untuk menghasilkan tembikar Tembeling ialah tanah yang apabila terkena mata cangkul akan kelihatan berkilat, tanah yang digali dengan cok seolah-olah menarik ketika ditarik naik, tanah tersebut akan melekat semasa dipicit dan tidak berderai apabila dikepal atau digenggam. Walau bagaimanapun, Ibrahim dan Sahaimi (2005) menolak pandangan tersebut apabila menyatakan bahawa tanah liat yang juga dikenali sebagai tanah Tembeling oleh penduduk setempat tersebut biasanya berwarna coklat kekuningan, mudah berderai apabila dipicit dalam proses pembuatan Terenang.

Bagi pengambilan tanah liat pula, proses ini biasanya akan bermula dari pagi hingga ke petang. Beberapa proses dan petua mesti dilalui ketika mengambil tanah liat. Lubang sedalam 1 hingga 2 meter digali menggunakan cangkul atau penggali dan tugasan ini hanya boleh dilakukan oleh orang lelaki sahaja. Lubang yang digali ada dua jenis iaitu lubang yang memanjang melintang dan lubang dalam ke bawah seperti telaga. Bagi tugas-tugas lain pula seperti pengumpulan, pembersihan, pengadunan dan sebagainya, semua tugasan tersebut dilakukan oleh wanita

Setelah tanah liat dijumpai, hanya tanah liat tulen sahaja diisikan ke dalam ambung (bakul yang digalas di belakang) dan dibawa balik. Tanah liat tersebut kemudian direndam ke dalam takung yang diperbuat dari kayu pulai atau tin sehingga tanah liat tersebut menjadi lembut. Tanah liat yang sudah lembut akan ditumbuk menggunakan papan alas setebal $8-10 \mathrm{~cm}$ yang biasanya diperbuat dari kayu tualang dan antannya pula bergaris pusat sebesar $8 \mathrm{~cm}$ dan $1 \mathrm{~cm}$ panjang. Namun ketika wujudnya bengkel industri, pengusaha mengunakan lesung indik dan menumbuk tanah liat kering. Setelah lumat, ia diayak lalu dibancuh dengan air supaya lembut dan mudah dibentuk.

Setelah kegiatan penghasilan tembikar di Kampung Pasir Durian terhenti, kawasan tanah rizab ini juga telah ditumbuhi belukar tebal dan sukar untuk dilawati. Temin Kraf tidak menggunakan tanah rizab 
ini tetapi telah membeli tanah dari pihak luar. Apabila permintaan semakin meningkat Temin Kraf telah mengambil langkah memproses tanah yang diambil dari sekitar bengkel bagi menjimatkan kos pengeluaran.

\section{Teknik Pembuatan (Reka Bentuk)}

Di dalam proses penghasilan secara tradisional bermula dengan proses pencarian tanah dengan penggalian tanah di tanah rizab. Pada masa dahulu tanah yang sudah lumat ditumbuk dan serbuk tanah liat yang siap dibancuh akan diuli seperti menguli tepung. Apabila tanah liat tersebut benar-benar lembut barulah ditempa dengan tangan menggunakan badang beralaskan papan alas.

Pembuatan tembikar tradisional secara keseluruhannya menggunakan kemahiran tangan menggunakan teknik picit cubit. Teknik picit cubit atau lingkaran merupakan teknik utama yang digunakan untuk membina dinding belanga. Hamdzun dan Narimah (2013) menyatakan proses pembuatan tembikar tradisional seperti Terenang, labu sayong, tembikar Mambong adalah hampir sama. Teknik picitcubit merupakan kaedah tradisional yang digunakan dalam mendapatkan bentuk tembikar. Kaedah ini memerlukan pinggan atau meja putar untuk memudahkan proses membina dinding tembikar. Kemahiran menggunakan kedua belah tangan untuk membentuk dan memusingkan pinggan akan membolehkan proses berjalan dengan lancar. Penggunaan penepek atau sudip kayu dipraktikkan bagi menepek permukaan dinding dengan tujuan akan memadatkan dan meratakan permukaan luar dinding tembikar. Proses ini dilaksanakan selepas proses membentuk keseluruhan siap dijalankan.

Selanjutnya, anak batu berbentuk lesung kecil pula digunakan dalam proses penerapan di bahagian tapak dengan menolak secara perlahan dari bahagian dalam supaya ia melengkung ke bawah (Ibrahim dan Sahaimi, 2005). Proses menguka pula bertujuan mengikis bahagian dalam dengan menggunakan kukur. Bagi mendapatkan permukaan Terenang yang berkilat, batu sungai digosokkan pada permukaan tembikar. Pengkaji mendapati penutup bertangkai dan pelapik adalah bentuk tambahan yang dibuat kemudian bagi melengkapkan bentuk Terenang.

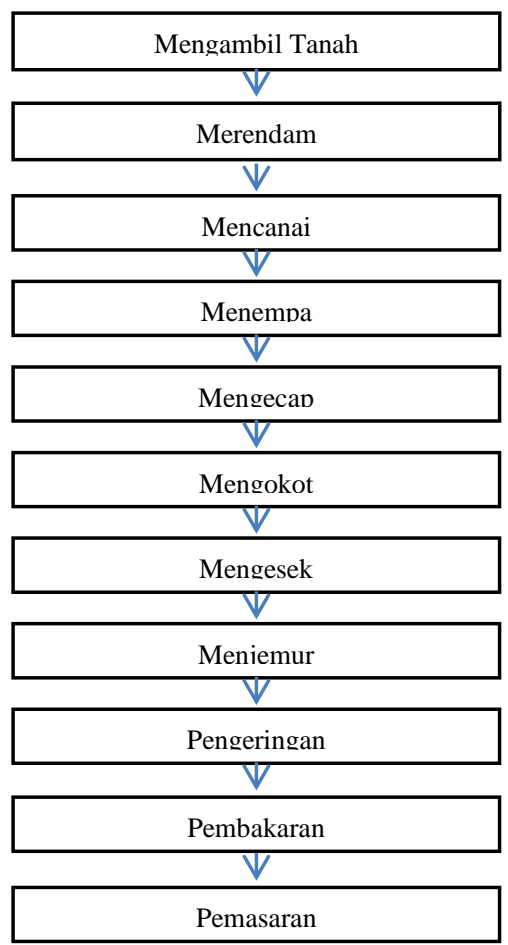

Rajah 2 Proses Penghasilan Tembikar Tradisional 


\section{Dekorasi Permukaan (Reka Corak)}

Tembikar tradisional Terenang dihiasi dengan motif-motif tradisional tempatan untuk menyerlahkan identiti tempat asal pembuatannya. Salwa Ayob (2011) telah mengumpulkan 30 jenis motif dari penggiat tetapi hanya 21 motif atau bunga yang dikenal pasti namanya.

Motif pada permukaan Terenang yang menghasilkan corak adalah hasil daripada hujung kayu pengecap atau kayu tera yang diukir. Kayu pengecap tersebut dihasilkan daripada kayu-kayu yang tahan lama seperti kayu hanyut yang dijumpai di tepi sungai. Proses mengecap ini melibatkan pengalaman dan kemahiran individu bagi memastikan motif yang dicap mengelilingi badan tembikar Terenang tidak akan bertindih. Kaedah ini masih diteruskan di Temin Kraf walaupun kaedah penghasilannya sudah berubah.

Selain daripada kaedah di atas, Temin Kraf juga menggunakan teknik gerlis pada permukaan Terenang supaya ia kelihatan seperti disaluti bahan berkaca. Kaedah ini menjadikan Terenang kelihatan lebih indah dan moden. Teknik gerlis merupakan teknik baru yang dipraktikkan kerana telah ada kemudahan yang mengizinkan pembakaran dibuat untuk teknik ini iaitu yang memerlukan suhu pembakaran sehingga $1200^{\circ} \mathrm{C}$.

Teknik lain yang digunakan juga ialah ukiran. Teknik ini merupakan satu kemahiran yang diadaptasi daripada ukiran kayu. Permukaan Terenang akan diukir dengan motif flora dan kebiasaannya dibakar pada peringkat biskut sahaja.

\section{Teknik Pembakaran}

Teknik pembakaran yang diamalkan dalam proses pembakaran Terenang mengunakan kaedah tradisional menggunakan kayu yang sesuai digunakan iaitu dahan-dahan kayu yang telah kering sebesar lengan kanak-kanak. Daun kelapa kering akan diletakkan di atas tanah dan kayu yang disusun di atasnya dalam bentuk empat segi bertindih-tindih dan berselang-seli. Terenang pula akan diletakkan di tengah-tengah susunan kayu tersebut.

Pembakaran bermula dengan membakar daun kelapa dan api tersebut akan dibiarkan marak sehingga semua kayu hangus dan menghasilkan bara yang akan diketepikan supaya tidak terkena tembikar. Tindakan ini bertujuan untuk mengelakkan kesan tompok-tompok hitam terbakar terhasil pada permukaan Terenang. Apabila pembakaran selesai, Terenang akan dibiarkan sejuk secara semula jadi dan kemudian disimpan. Selain daripada pembakaran secara terbuka, kaedah pembakaran menggunakan gok atau tanur juga digunakan. Gok dibina daripada batu-bata dan proses pembakaran menggunakan bahan daripada kayu.

Di Temin Kraf, kaedah pembakaran adalah dengan menggunakan tanur gas. Penggunaan tanur gas membolehkan pembakaran yang dilakukan dikawal dengan sempurna oleh penggiat. Pembakaran tanur gas boleh mencapai suhu di antara $800-1200^{\circ} \mathrm{C}$ iaitu pembakaran secara biskut dan hiasan gerlis dapat dibuat pada Terenang. Selain itu, pengusaha tembikar Tembeling di Kampung Pasir Durian, Hajah Noriah ketika masih aktif juga mendapatkan bantuan Temin Kraf bagi tujuan pembakaran menggunakan tanur gas.

\section{Fungsi dan Kegunaan}

Terenang berfungsi untuk kegunaan perubatan tradisional seperti upacara jampi serapah bagi mengisi air mawar asli sebagai ubat penawar dan mengangkut serta menyimpan air. Jika Terenang yang telah digunakan dikeringkan dengan diletak di atas para, dipercayai air yang dimasukkan ke dalamnya akan sentiasa sejuk dan berbau wangi. Berdasarkan perkembangan masa, fungsi asal Terenang sebagai bekas atau tabung air semakin terpinggir dan dilupakan. Hal ini berlaku kerana terdapat banyak persaingan produk moden yang dihasilkan seperti botol plastik, besen dan sebagainya di pasaran. 


\section{METODOLOGI KAJIAN}

Penyelidikan ini merupakan kajian kualitatif yang merakamkan secara deskriptif tembikar tradisional Terenang yang dihasilkan Temin Kraf di Jerantut, Pahang. Kajian ini memfokuskan kepada aspek bahan mentah, teknik pembuatan, dekorasi permukaan dan teknik pembakaran. Data-data kajian diperolehi melalui proses permerhatian, temubual dan analisis dokumen (Jadual 1).

Jadual 1 Matrik Pengumpulan Data

\begin{tabular}{lccc}
\hline \multirow{2}{*}{ Kategori } & \multicolumn{3}{c}{ Teknik Pengumpulan Data } \\
\cline { 2 - 4 } & Pemerhatian & Temubual & Analisis Dokumen \\
\hline Bahan Mentah & $\checkmark$ & $\checkmark$ & \\
Teknik Pembuatan & $\checkmark$ & $\checkmark$ & $\checkmark$ \\
Dekorasi Permukaan & $\checkmark$ & $\checkmark$ & \\
Teknik Pembakaran & $\checkmark$ & $\checkmark$ & \\
\hline
\end{tabular}

Analisis data dijalankan sebaik sahaja kutipan data dilakukan dan ia merupakan proses yang berterusan. Data-data yang telah dikumpulkan melalui proses pengurangan (reduction) kepada kategori atau tema yang telah ditentukan. Proses ini diikuti dengan proses interpretasi.

\section{DAPATAN KAJIAN}

Terenang yang dihasilkan di Temin Kraf masih lagi mengekalkan bentuk yang dihasilkan di Kampung Pasir Durian tetapi beberapa perubahan pada bahagian leher dan dada dibuat untuk disesuaikan dengan teknik acuan tuang. Kelebihan pembuatan di Temin Kraf ialah Terenang boleh dihasilkan dengan pelbagai saiz bersesuaian dengan fungsi yang dirancang atau yang diminta oleh pengguna. Kebanyakkan reka bentuk Terenang yang dihasilkan juga tidak lengkap iaitu tidak semua yang dihasilkan mesti mempunyai penutup atau pelapik. Adakala hanya Terenang sahaja yang dihasilkan tanpa disertakan dua bentuk ini. Berdasarkan kajian melalui proses pemerhatian, temubual dan analisis dokumen dapatan kajian boleh dikategorikan kepada 4 proses yang melibatkan aktiviti penghasilan Terenang dari awal hingga akhir.

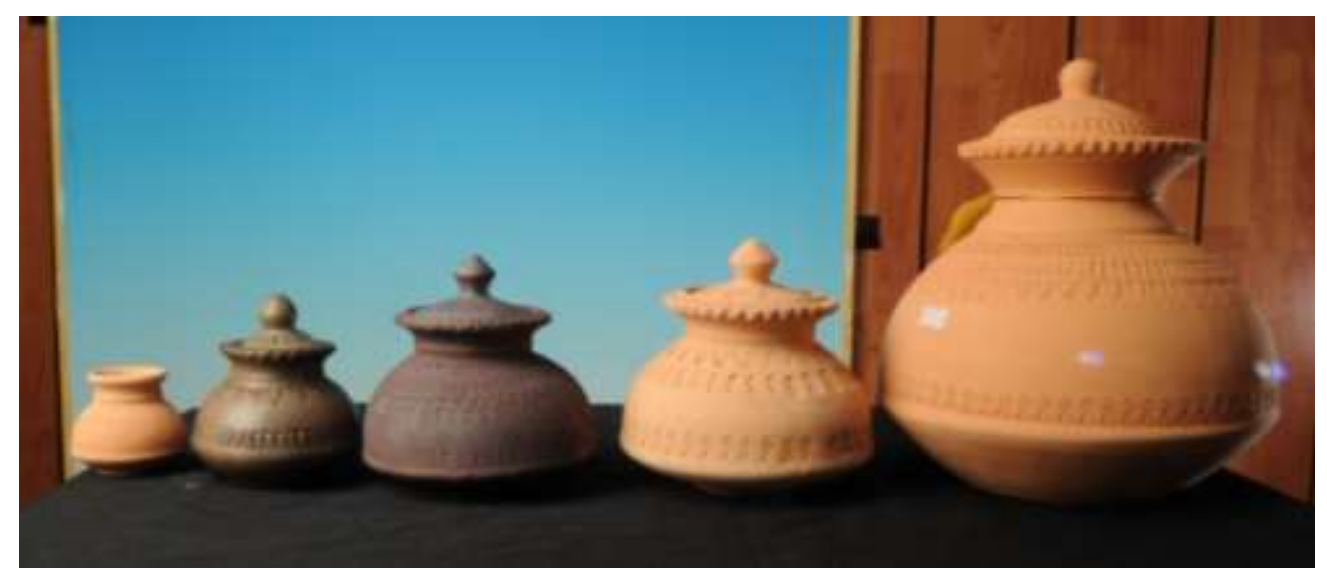

Rajah 3 Reka Bentuk Terenang yang dikeluarkan di Temin Kraf

\section{Proses Bahan Mentah}

Bahan mentah utama dalam penghasilan Terenang ialah tanah liat tetapi di Temin Kraf penggunaannya tidak lagi menggunakan tanah yang diambil dari Kampung Pasir Durian. Menurut penggiat di Temin Kraf, terdapat perbezaan kualiti tanah dari dua kawasan ini. Ini dapat diperhatikan semasa proses pemprosesan 
iaitu proses tanah di Temin Kraf melibatkan penggunaan mesin berbanding Kampung Pasir Durian. Dari segi kualiti tanah, dari Kampung Pasir Durian adalah lebih baik kerana boleh terus digunakan selepas direndam tanpa melibatkan penggunaan bahan-bahan campuran lain. Di Temin Kraf, tanah yang diperolehi bukanlah dalam keadaan fizikal sebenar tanah liat yang lembut tetapi ianya agak keras, kasar dan berketul. Untuk membolehkan tanah ini digunakan ia akan diproses menggunakan peralatan-peralatan berbentuk mesin bagi menukarkan ia dalam bentuk cecair tanah yang pekat atau slip. Diperhatikan terdapat dua jenis mesin yang digunakan iaitu mesin ball mill dan blunger.

Mesin ball mill berperanan menghancurkan ketulan tanah dan juga menggaul tanah dengan campuran bahan-bahan lain seperti grob, pasir, air, sodium silikat untuk menjadikan ia sebagai satu cecair pekat atau slip. Proses ini juga akan menghaluskan tanah liat berserta campuran bahan lain yang dinyatakan. Ianya mengambil masa sekitar tiga jam dan lebih lama proses diteruskan lebih halus campuran tanah liat yang akan diperolehi. Tanah yang dikeluarkan dari mesin akan diperam untuk tempoh tertentu. Tanah yang diperam akan dimasukkan ke dalam mesin blunger jika proses penghasilan akan bermula. Mesin blunger pula bertindak untuk mengacau tanah liat dengan air. Terdapat bilah-bilah kipas yang berputar perlahan yang berfungsi untuk mengelakkan tanah dari mendap ke dasar.
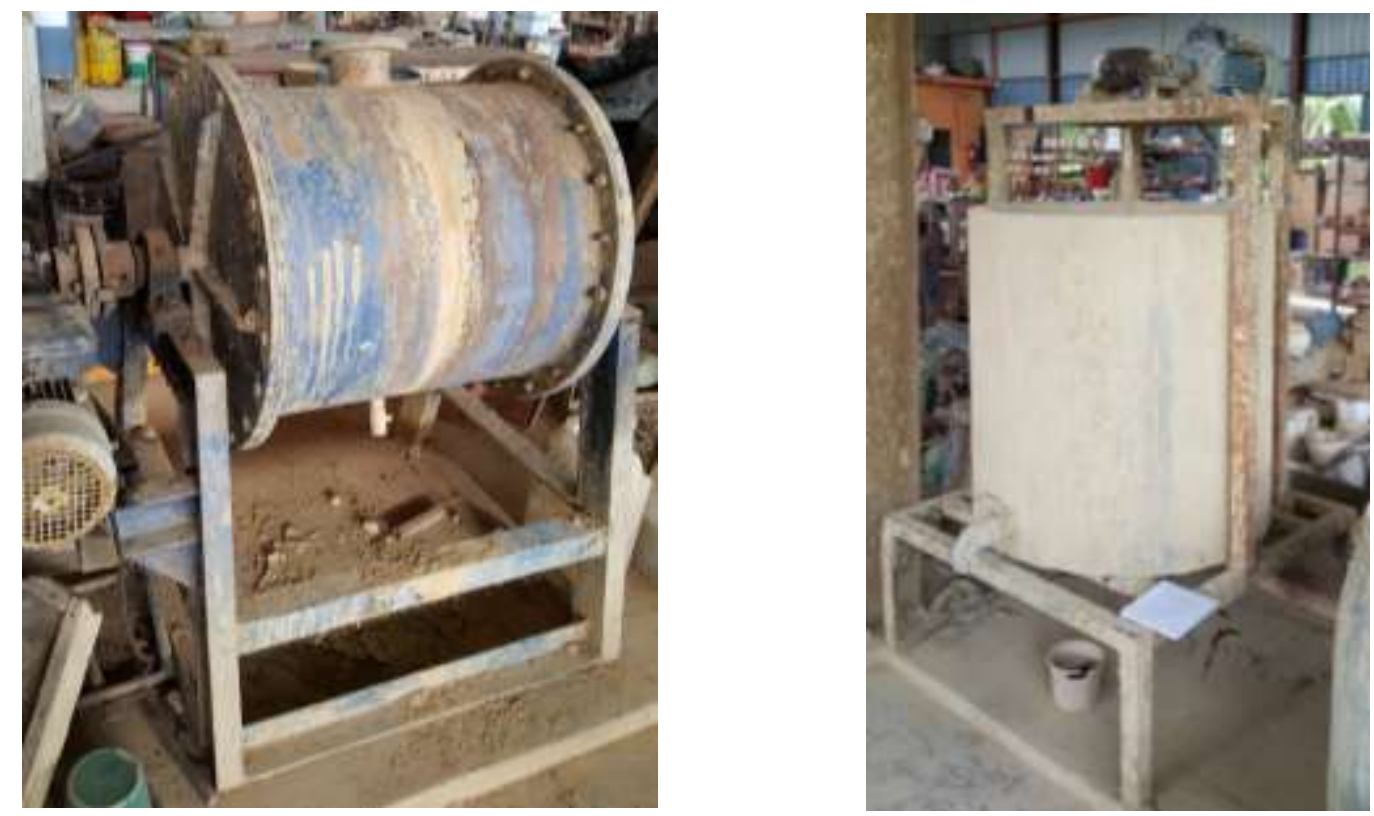

\section{Proses Reka Bentuk}

Tanah yang dikacau menggunakan mesin blunger akan dikeluarkan ke dalam bekas seperti baldi bergantung pada kuantiti yang diperlukan. Tanah liat dalam keadaan cairan slip akan dituangkan ke dalam acuan yang diperbuat dari kapur atau dikenali sebagai Plaster of Paris. Acuan tuang ini berperanan untuk membentuk cairan slip menjadi Terenang. Acuan yang berisi slip akan dibiarkan untuk tempoh satu jam hingga tiga jam dan pada selang masa sekitar 20 hingga 30 minit akan diperiksa oleh penggiat untuk memastikan slip akan membentuk dinding Terenang mengikut ketebalan yang tepat iaitu sekitar 1-5 mm. Jika dinding telah mula terbentuk, cairan slip yang berlebihan akan dikeluarkan tetapi acuan akan dikembalikan ke keadaan asal untuk mengeringkan jasad Terenang secara perlahan-lahan di dalam acuan. Apabila Terenang dikeluarkan dari acuan ianya masih lagi dalam keadaan belum kering sepenuhnya atau dengan permukaan yang masih lembab. Terenang akan dibiarkan kering secara semula jadi di rak untuk proses seterusnya iaitu dekorasi. Penggunaan acuan Tuang membolehkan Terenang dihasilkan dalam pelbagai saiz, jumlah yang banyak dan proses pembuatan yang lebih pantas. Penghasilan Terenang di Temin Kraf bergantung sepenuhnya dengan acuan tuang. Berdasarkan pemerhatian pengkaji, pengeluaran produk-produk selain Terenang seperti belanga, labu, perasapan tidak dibuat kecuali kendi. Ini mungkin 
disebabkan kendi dihasilkan menggunakan acuan Terenang dan ditambah muncung menggunakan kemahiran tangan.

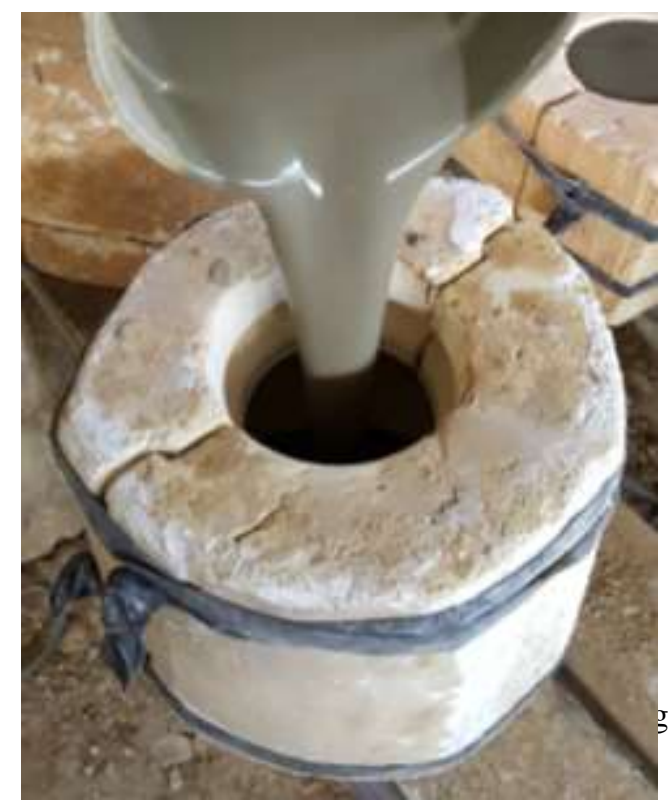

\section{Proses Dekorasi}

Proses dekorasi di Temin Kraf boleh dibahagikan kepada 4 kaedah iaitu terapan, ukiran, sapuan cat dan gerlis. Terapan merupakan kaedah memindahkan motif dari kayu tera ke atas permukaan Terenang. Kayu tera merupakan alat tempa yang berupa kayu kecil yang kedua-dua muka hujungnya bermotif. Motif dipindahkan dengan menekan hujung kayu ke atas permukaan Terenang. Kayu ini kebanyakannya diwarisi dari penggiat dari Kampung Pasir Durian tetapi ada juga yang ditempah semula untuk mendapatkan motif yang lebih jelas. Terapan pada Terenang kebiasaannya dibuat pada bahagian mulut, leher, dada dan pada bahagian sempadan badan dan buntut. Terdapat dua hiasan yang kerap digunakan dan menjadi identiti Terenang ialah hiasan Gigi Jawa dan Tali Air. Gigi Jawa terletak di sekeliling mulut Terenang dan Tali Air pula merupakan garisan pemisah antara leher dan dada, dada dan badan atau badan dan buntut. Di Temin Kraf, kaedah pembuatannya masih mengekalkan cara dari Kampung Pasir Durian tetapi untuk Tali Air kelihatan seperti sudah tersedia garisan timbul yang dibuat sekali di dalam acuan.

Temin Kraf juga memperkenalkan teknik ukiran pada permukaan Terenang. Ini merupakan teknik baru yang tidak pernah digunakan pada Terenang dari Kampung Pasir Durian. Menurut penggiat teknik ini dipelajari dari Sayong, Perak ketika masih belajar. Motif yang digunakan berbentuk daun dan bersaiz besar. Motif ini biasa kelihatan pada tembikar-tembikar yang dikeluarkan dari Sayong. Teknik ini memerlukan kemahiran penggiat untuk mengukir motif menggunakan tangan semasa Terenang masih dalam keadaan lembab. Di Temin Kraf, sebelum teknik ukiran dimulakan- latar permukaan pada bahagian yang akan diukir akan disapu dengan cat yang berwarna putih atau merah. Cat ini diperbuat dari tanah atau dengan mencampurkan sedikit bijih besi untuk warna merah. Latar yang dicat akan memberikan penegasan terhadap motif yang diukir.

Gerlis merupakan satu kaedah lagi yang digunakan untuk mengindahkan Terenang. Penggunaan gerlis menjadikan permukaan jasad Terenang tampak lebih menarik kerana kelihatan seperti diperbuat dari bahan berkaca. Terdapat pelbagai warna gerlis dihasilkan samada dibeli atau diproses oleh Temin Kraf. Gaya menghias menggunakan gerlis kebiasaannya ia disapu pada keseluruhan permukaan Terenang sama ada dicelup atau disapu. Pengunaan satu atau dua warna memudahkan penggiat mengawal dan menyeragamkan hiasan yang menggunakan gerlis. Kaedah menyapu gerlis selalunya sesudah Terenang dibakar secara biskut dan selepas disapu gerlis ia akan dibakar sekali lagi pada suhu yang menjangkau $1200^{\circ} \mathrm{C}$. 


\section{Proses Pembakaran}

Proses pembakaran yang dipraktikkan di Temin Kraf ialah menggunakan tanur gas. Kaedah ini menurut penggiat menjimatkan masa dan pembakaran yang dilakukan lebih sempurna. Didapati tanur gas, suhu pembakaran adalah di antara $800-1000{ }^{\circ} \mathrm{C}$ yang mengambil masa 3 hingga 5 jam.

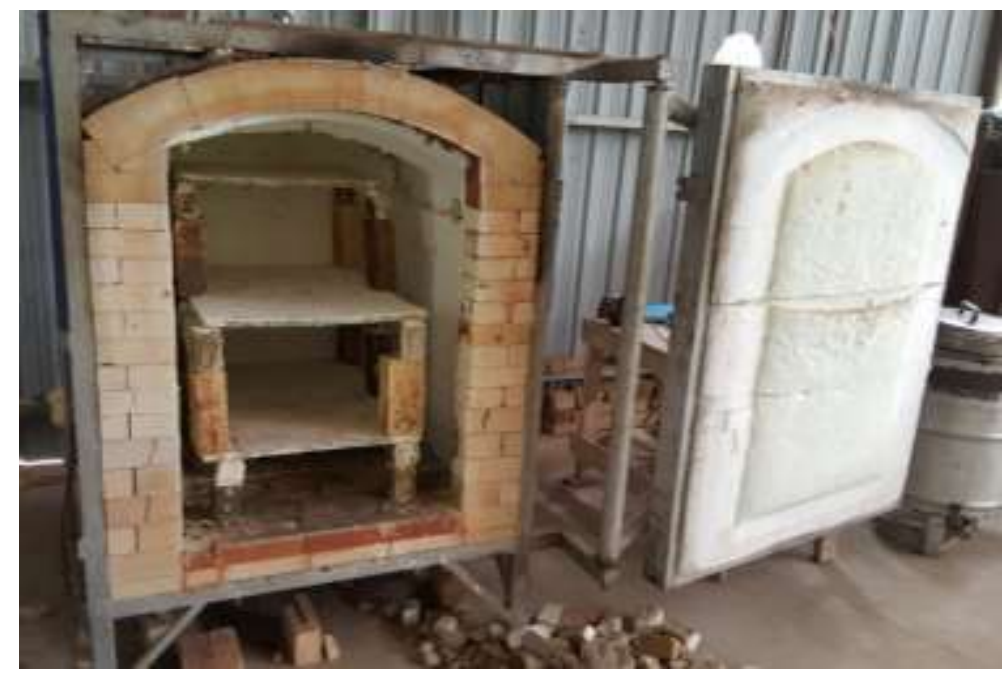

Rajah 7 Tanur Gas binaan sendiri di Temin Kraf

\section{KESIMPULAN}

Dapatan kajian menunjukkan teknologi penghasilan Terenang di Temin Kraf adalah lebih moden berbanding yang dipraktikkan di Kampung Pasir Durian. Didapati teknologi memainkan peranan yang penting untuk pengeluaran Terenang. Setiap peralatan atau mesin yang digunakan mempunyai fungsi tersendiri yang boleh mendatangkan manfaat kepada pembuat tembikar. Melalui teknologi, proses pembuatan Terenang berjalan dengan lancar sekali gus menjadikan kehidupan mereka lebih mudah. Kajian ini telah menunjukkan bahawa teknologi moden menggunakan mesin telah dilaksanakan dengan jayanya dalam membuat tembikar tradisional Terenang tetapi pada masa yang sama terdapat juga bahagian yang memerlukan pembuatan secara manual menggunakan tangan. Ini menunjukkan bahawa di samping mengekalkan cara lama dalam teknologi, pemodenan juga memberikan sumbangan yang besar dalam aspek saintifik dan peralatan yang digunakan. Teknologi yang digunakan juga secara tidak langsung menyumbang kepada proses pembuatan yang lebih cekap dan akan meningkatkan produktiviti Terenang tradisional. Tajul Shuhaizam Said et al. (2011) menyatakan pembangunan perkembangan budaya bermula dari proses penghasilan yang mudah hingga melibatkan penggunaan teknologi adalah mencerminkan kebijaksanaan pengusaha tembikar tradisional. Pengetahuan penggiat tembikar khususnya Terenang dalam bidang ini juga telah bertambah terutama dalam aspek kepakaran teknikal yang menyumbang kepada inovasi pembuatan, teknik hiasan dan pembakaran. Perkembangan ini telah membuktikan bahawa bakat dan kemahiran dalam kalangan penggiat yang mengaitkan pelbagai proses menggunakan teknologi telah menyumbang kepada kelestarian kegiatan pembuatan tembikar di Malaysia pada keseluruhannya.

\section{RUJUKAN}

Abdul Rahim Jalil, Oskar Hasdinor Hassan, Norhidayah Md Zainuddin, Hamdzun Haron. (2012). Alternative techniques of blackening labu sayong. Jurnal Teknologi. Johor: Penerbit UTM.

Azmi Arifin, Muhamad Luthfi Abdul Rahman \& Tarmiji Masron. (2010). Warisan tembikar labu sayong di Kuala Kangsar, Perak. Sejarah, perkembangan dan masa depan. Sari - International Journal of the Malay World and Civilisation. Bangi: UKM.

Ensiklopedia Sejarah dan Kebudayaan Melayu. (1999). Kuala Lumpur: Dewan Bahasa dan Pustaka. 
Enoch, O. F. (2012). The act of mass production in Kelantan traditional pottery, Malaysia. The International Institute for Science, Technology and Education (IISTE). 3: 18-26.

Glosari Budaya Malaysia: Seni Tembikar. (1992): Kuala Lumpur. Dewan Bahasa dan Pustaka.

Hamdzun Harun, Narimah Abd. Mutalib. (2012). Aspek estetika labu acu malim. Jurnal Pengajian Umum Asia Tenggara. Bangi: UKM.

Hamdzun Harun, Narimah Abd. Mutalib. (2013). Technology and production process of Malay traditional heritage pottery in Malaysia. Jurnal Teknologi. Bangi: UKM.

Hamdzun Haron, Nor Afian Yusof, Liza Marziana Mohammad Noh, Narimah Abd Mutalib. (2013). Technology and production process of Malay traditional heritage pottery. Jurnal Teknologi. 20: hlm 85-88.

Hamdzun Haron. (2013). Akal rekaan pandai seni warisan Melayu. Bangi: Institut Alam dan Tamadun Melayu (ATMA).

Mohd Kamaruzaman A. Rahman. (1997). Hoabinh di Pahang dalam pembangunan arkeologi pelancongan Negeri Pahang. Pekan Pahang: Lembaga Muzium Negeri Pahang.

H. N. Evans. (1922). The potting industry at Kuala Tembeling. F.M.S 9(4), 259-262.

Ibrahim Darus, Shahaimi Abdul Manaf. (2005). Tembikar tradisional. Kuala Lumpur: Perbadanan Kemajuan Kraftangan Malaysia.

Nurul Izzah Mohd Johari. (2011). Seni tembikar tradisional Terenang Pahang tradisi dan perubahannya. Tesis Sarjana. Universiti Pendidikan Sultan Idris, Tanjong Malim.

Salwa Ayob. (2011). Kesinambungan perubahan pemerian jasad dan rupa tembikar pra sejarah kepada tembikar tradisi Melayu. Pulau Pinang: Penerbit USM.

Syed Ahmad Jamal. (1997). Rupa dan jiwa. Kuala Lumpur: Penerbit Universiti Malaya.

Tjetjep Rohendi Rohidi, Abdul Halim Husain. (2015). Metodologi penyelidikan seni. Tanjong Malim: Penerbitan Malim Sarjana.

Tajul Shuhaizam Said, Harozila Ramli, Mohd Fauzi Sedon. (2011). Local genius of mambong pottery in Kelantan, Malaysia. International Journal of Humanities and Social Science, 1(21): 147-155.

Zahirah Harun, Nor Nazida Awang, Hamidi Abdul Hadi dan Asyaari Muhammad. (2015). The characterization of Kuala Tembeling Clay Pottery: Form and Cultural Function.

Zahirah Harun. (2016). Keindahan tembikar Melayu tradisional Kampung Pasir Durian. Tesis Doktor Falsafah. Universiti Kebangsaan Malaysia, Bangi.

Zainal Zakaria, Oskar Hasdinor Hassan. (2006). Pembangunan jasad terracotta bagi pengusahaan seramik di negeri Pahang. Selangor: UiTM.

Zainal Arifin Ahmad, Abdul Rashid Jamaludin, Muhammad Azwadi Sulaiman. (2014). Seni tembikar. Pulau Pinang: Penerbit Universiti Sains Malaysia.

Zakaria Ali. (1989). Seni dan seniman esei-esei seni halus. Kuala Lumpur: Dewan Bahasa dan Pustaka. 